\title{
Planning and designing
}

\section{low-carbon cities in Mexico*}

\begin{tabular}{|c|c|c|}
\hline \multirow{2}{*}{\multicolumn{3}{|c|}{$\begin{array}{l}\text { Received: March 14, } 2017 \text { Accepted: December 12, } 2017 \text { Av } \\
\text { Silverio Hernández Moreno } \\
\end{array}$}} \\
\hline & & \\
\hline $\begin{array}{l}\text { Universidad Autónoma del } \\
\text { Estado de México }\end{array}$ & $\begin{array}{l}\text { ORCID: https://orcid.org/0000-0002-4971- } \\
8705\end{array}$ & silverhm2002@yahoo.com.mx \\
\hline \multicolumn{3}{|c|}{ José Antonio Hernández Moreno } \\
\hline $\begin{array}{l}\text { Colegio de Posgraduados, } \\
\text { México }\end{array}$ & $\begin{array}{l}\text { ORCID: https://orcid.org/0000-0002-1009- } \\
4595\end{array}$ & tecnobiosfera27@gmail.com \\
\hline \multicolumn{3}{|c|}{ Bianca G. Alcaraz Vargas } \\
\hline $\begin{array}{l}\text { Universidad Autónoma } \\
\text { Chapingo, México }\end{array}$ & $\begin{array}{l}\text { ORCID: https://orcid.org/0000-0002-2140- } \\
2530\end{array}$ & alcarazbg@gmail.com \\
\hline
\end{tabular}

Abstract This paper proposes an urban cluster designed for use in planning of low-carbon cities in Mexico, starting from the methodological basis of environmental design models in buildings such as LEED Neighborhoods, Breeam Communities and Conavi CEV Mexican Code, and from several design strategies of smart planning based on the integration of several land uses, both urban and rural types; where it is proposed (in addition to housing use, commerce use, green areas use, etc.) areas for urban agriculture and urban areas for the generation of alternative and green energy. It is concluded that the design of the cluster can be functional as an urban design pattern and be useful in smart planning of cities and can also be a starting point for planning of rural-cities.

Keywords Low-carbon design; rural-cities; smart planning; urban clusters; urban patterns 


\section{Planear y diseñar}

ciudades de bajo carbono en México

Resumen Este artículo propone un clúster urbano para la planeación de ciudades de bajo carbono en México, a partir de modelos de diseño ambiental en edificios como el de Barrios, de LEED; el de Comunidades, de Breeam y el Código CEV, de la Conavi de México, así como de estrategias de diseño sobre planeación inteligente de ciudades basadas en la integración de usos de suelo tanto urbanos como rurales. En complemento con el uso de suelo para vivienda, comercio, áreas verdes, etc., se proponen áreas para agricultura urbana y para la generación de energía alternativa y ecológica. Se concluye que el diseño del clúster funciona como patrón de diseño urbano, es útil en la planeación inteligente de ciudades y puede ser un punto de referencia para la planeación de ruraciudades.

Palabras clave clúster urbano; diseño de bajo carbono; patrones de diseño urbano; planeación inteligente; ruraciudades

\section{Planejamento e projeto}

de cidades de baixo carbono no México

Resumo Este artigo propóe um aglomerado urbano projetado para uso no planejamento de cidades de baixo carbono no México, com base metodológica de modelos de projeto ambiental em edifícios como o LEED Barrios, a de Comunidades Breeam eo CEV Código Conavi do México, bem como várias estratégias de projeto baseado em planejamento inteligente a integração de vários usos de terra em cidades urbanas e rurais; onde é proposta (em complemento com o uso da terra para habitaçáo, comércio, áreas verdes, etc.) áreas para agricultura urbana, e para a geração de energia alternativa e ecológica. Conclui-se que o projeto do padrão de cluster pode funcionar como urbana e muito útil no planejamento do projeto e da cidade inteligente pode ser um ponto de referência importante para o planejamento Rura-cidades.

Palavras chave aglomerado urbano; projeto de baixo carbono; padrões de projeto urbano; planejamento inteligente; rura-cidade 


\section{Introduction and problem statement}

Low-carbon cities are those that to be urbanized, operated and maintained release relatively low carbon amounts and their equivalents into the atmosphere (Wang \& Prominski, 2016; City of Copenhagen, Technical and Environmental Administration, 2012; Drake, 2014; Chase \& Lawrence, 2010; La Roche, 2012). A low-carbon city involves smart planning and sustainable design, by means of which it is sought to reduce and mitigate the environmental impacts that cities generate over their entire life cycle.

To understand the life cycle of a city, we must separate the cities in their various infrastructure parts, as each of these components has its own service life and durability and they also depend on their historic and economic period. Cities are known to be complex, dynamic, and highly integrated systems that evolve over time and separating their lifecycle phases and predict their service life accurately can be complicated (McPhearson, Haase, Kabisch \& Gren, 2016). Figure 1 summarizes the life cycle of an average Mexican city.

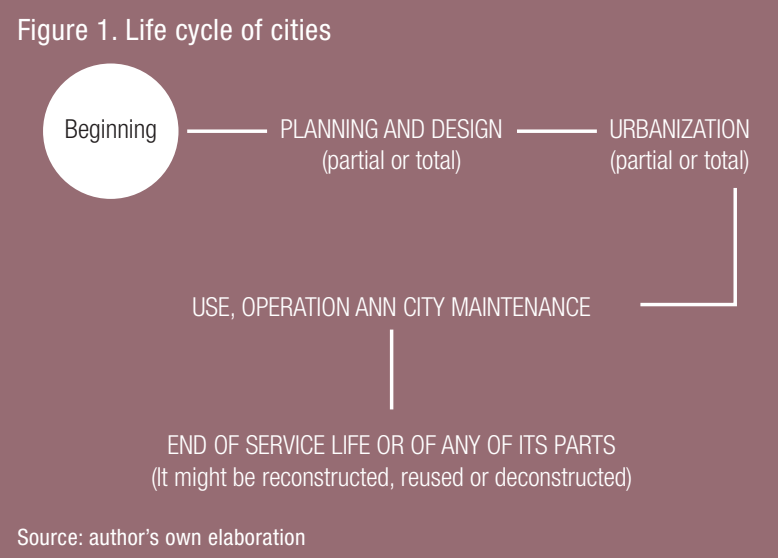

The problem of fast and uncontrolled urbanization (urban sprawl) partially lies in the inoperative design of neighborhoods, linked to bad planning in the use of urban land, as well as in other demographic problems such as countryside-city migration; economic ones, lack of employment and food; and even cultural and social, for instance discrimination of rural culture and habits and customs of indigenous people, which is in fact, the origin of most of the urban population nowadays, as before 2010 most of the population was located in rural zones and almost all urban population has urbanized (United Nations, 2008).

The aim of this document is to generate a prototype or proposal of urban cluster design (based on building by blocks) that works as a design pattern to plan low-carbon cities under the smart urban planning criterion, propitiating solutions that generate employment, food and small and mid-scale energy production in the cities, thus helping regional sustainable development and improving the quality of life of many urban inhabitants in the present and the near future.

In Mexico, as everywhere, the traditional model to plan cities has concentrated the population in inefficient and unproductive urban and semi-urban zones that deepen social inequality and generates pollution and environmental impacts that put at risk many people to climate change (Molina, 2014).

Most of the cities in the world are based on an economy that consumes fossil fuels with heavy 
carbon emissions into the atmosphere, which cause the widely known problems of global warming and climate change (Cheung \& Fan, 2013; Van der Werf et al., 2009; Bin Marsono \& Balasbaneh, 2015; Fouquet et al., 2015; Centro Mario Molina, 2014). On the other side, the planning and design of cities have a preponderant role in mitigating and reducing carbon footprint at local and global scales; this way, it is necessary to propose a radical change in the way cities are designed and planned in order to counteract the effects of climate change, which it can summarize in the following points:

, Air, soil and water pollution.

, Decrease of phreatic levels.

, Fragmentation of the natural environment and biodiversity.

, Sea level rise.

, Variation in wind speed (Carmin, 2009).

, Variation in precipitation.

, Changes in flora and fauna (Carmin, 2009).

> Increase in country-to-city migration.

, Long heat periods.

, Increase of heat island effects (Carmin, 2009).

> Variation in the temperature and humidity of the environment (Carmin, 2009).

, Extinction of species of flora and fauna.

, Extreme heat waves and cold fronts.

, Increment of sea levels at global scale, producing tsunamis and alterations in ocean and air currents.

, Changes in the amount of mean, maximal and minimal pluvial precipitation, producing floods (Carmin, 2009).

, Extreme droughts and other associated problems such as hydrologic cycle affectations.
Wildfires with no apparent cause.

, Erosion in previously unaffected zones (Car$\min , 2009)$.

, Damage to food, forest, agricultural, mining, transport and fishing production.

There are worrying data on the global urbanization levels required in the near future; for instance by 2035, China will need to build new cities to hold about 350 million people, only in 20 years' time (McKinsey \& Company, 2009).

The following questions are partially or fully answered in the present research work:

1. Which sector in Mexico produces the most carbon emissions into the atmosphere?

2. How can architects and urbanists reduce and mitigate the carbon footprint produced by the cities?

3. How can we reduce the consumption of natural resources in the cities to improve their metabolism without decreasing the inhabitants' quality of life?

A priory, we can anticipate our answers to the previous questions. The first answer to this set of questions is that urbanists and architects shall design and plan low-carbon cities with low environmental impacts as a general rule. Secondly, urban development plans must consider suitable and productive land uses, both in the urban and rural environments. Subsequently, architects and urbanists should know cities are complex systems and these subdivide in sub-systems, each with a specific function that will have an influence on the rest of the system and an impact on the subsystems. Some of the most important of these sub-systems are:

Urban morphology (shape, layout and structuring). 
, Land uses.

, Infrastructure and equipment (energy, telecommunications, waterworks, transport, etc.).

, Urban mobility.

, Population.

, Migration.

- Economic activities (manufacture, services, food production).

- Social activities (culture, education, leisure, etc.).

, Climate impacts.

, Government.

The hypothesis which the present work is based upon is that smart urban planning should be supported on the design of low-carbon urban clusters (Figure 2) composed of neighborhoods with various land uses (at an urban-architectural or meso-scale) arranged in such manner that they reduce the environmental impacts in the cities, therefore each urban and architectural configuration has a determinate level or degree or carbon footprint.

It would be important and to complement the hypothesis, that these blocks edified from urban clusters incorporate in their urban land uses, those typical of the rural sphere such as agriculture and small and mid-scale energy production, in views of offering partial solutions to the largest problems of urban zones, i.e., green energies and food production activities.

Thereby there would be a new sort of city, which we have called rural-city or ruralized city; it is a low-carbon one and incorporates smart solutions for the development of cities, mainly in developing countries such as Mexico and Latin America.
The consumption of energy from fossil fuels to build and operate all the cities in the world produces approximately $50 \%$ of the total harm from global warming (Van der Werf et al., 2009; Bin Marsono \& Balasbaneh, 2015; Fouquet et al., 2015), so architects and urbanists shall face and solve these problems at various scales, from the architectural or micro scale to a metropolitan or macro scale so that there can be a global-scale incidence.

Figure 2. Urban cluster according to certain land uses

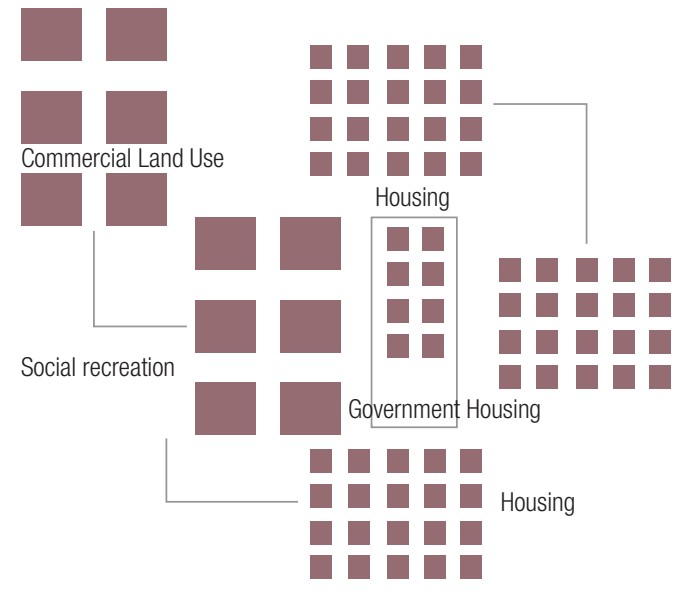

Source: author's own elaboration

Besides, land uses markedly influence the urban dynamics of the cities as well. They can increase or reduce to a large extent the environmental, economic, migratory effects and also those from "urban metabolism" proper to the cities; this understood as the physical study of the resources flows required to maintain the economy of a city (Fernandez, 2014). This is to say, the way in which resources are consumed in a city or human settlement, therefore these land uses have to be controlled so that they do not interfere with the growth of the cities and with the human activities there performed. 


\section{Methodology}

The aim of the present document is to generate and design a low-carbon urban cluster that works as a design pattern for the smart planning of cities. The object of the study was the constructed urban environment, limited to Mexican and Latin American cities, which have similar problems and defects.

The approached problem, as already mentioned in the introduction, was that frequently cities grow in a disordered manner, and at the same time this generates a number of problems in the demographic structure of the cities, as it is the case of countryside-city migration, lack of employment and food and the decrease of the quality of life in the cities, in addition to all the environmental impacts, related to soil, air and water that cities generate, accompanied by carbon emissions into the atmosphere. Therefore, in this study the dependent variable or response variable is the amount of carbon dioxide emissions emitted by the cities; and the control variables or independent variables could be different resources flows that pass through the city for its operation and maintenance, also measured in carbon dioxide emissions during a certain time of service life of the city, urban cluster or neighborhood.

Formula 1 can express the estimation of carbon dioxide emitted by the cities or urban clusters as an indicator of its urban metabolism:

$$
E C O_{2}=D S L \sum_{i=F 1}^{F 9} i
$$

Where:

$\mathrm{ECO}_{2}=$ Estimation of Carbon Dioxide emitted by the cities, urban clusters or neighborhoods ( $\mathrm{CO}_{2}$ tons);
$D S L=$ Design Service Life of a particular city, urban cluster or neighborhood, etc. (years);

$\mathrm{i}=$ Index;

F1-F9= Summands (resources flows);

Resources flows ( $\mathrm{CO}_{2}$ tons) as factors influencing the Estimation of Carbon Dioxide emitted by the cities:

F1= Self-consumption;

F2 = Electric generation;

F3 = Manufacture and Construction industry;

F4 = Transport;

F5 = Commerce;

F6 = Residential;

F7 = Agricultural;

F8 = Mining and Carbon handling;

F9 = Oil and Gas industry.

The particular method utilized to reach a low-carbon urban design proposal was to first limit the urban space of the cities at an urban-architectural or meso-scale in which a model or pattern called urban cluster was generated to later apply a number of environmental design strategies (Table 1) and smart design criteria were used (strategies to design low-carbon clusters).

Strategies of sustainable design previously generated by the author of this document by means of revising various environmental design models, mainly the American LEED Neighborhoods model, the United-Kingdom Breeam Communities model and CEV Code by Mexican Conavi (Comisión Nacional de Vivienda, 2015) [National Housing Commission]. In views of 
proposing an own model of sustainable design of cities in Mexico to incorporate into the cluster aspects referring to the sustainable management of the site, water, energy, materials, waste and comfort, thus propitiating an environmental design.

On the other side, the design strategies for low-carbon urban cluster have also been proposed from revising models, methods, regulations and information that answered the following question: how can we reduce the consumption of resources in the cities to improve their metabolism without decreasing the inhabitants' quality of life? This way, arose the idea of designing an urban pattern that sets the example to plan cities with a low-carbon footprint without compromising their inhabitants' quality of life.

Subsequently, a low carbon cluster proposal was designed through the following urban and architectural design criteria (strategies and design key points):

Firstly, the causes for resource consumption in the cities must be defined and identified:

a) The first and the one with the heaviest environmental impact, is the energy item and impacts produced by the use, operability and maintenance of infrastructure, mainly: electricity, gas, water and generation of solid and liquid waste.

b) Emissions and consumption of fuels (gasoline, diesel and other fuels for transport and mobility).

c) Impacts caused by construction of buildings, measured in the carbon contained in the constructive materials and processes, produced from raw material extraction, materials manufacture to the construction processes. d) Other impacts such as food production, livestock and industrial sectors and adverse climatological and physical effects.

Two direct solutions that are proposed to reduce resource consumption are: 1) produce energy inside the cities, decrease energy and water consumption, and reduce both solid and liquid waste; 2 ) in order to improve the urban "metabolism" in the cities, incorporate urban agriculture and food production in the cities at an urban-architectural or meso-scale.

Secondly, the strategies and key points for low-carbon urban cluster design are listed:

a) Vertically densify urban infrastructure and equipment (construction), including of course: housing, commerce, government, industry, education and other services by means or urban blocks to decrease the traditional size of large, horizontal and sprawled cities.

b) Decrease horizontal urban circulations, this is to say, avenues, roads and streets, in views of increasing circulation of pedestrians, bicycles and mass public transport, such as light rail and buses.

c) Use of urban patios and solaria to illuminate and ventilate building blocks.

d) Use of urban reticules to have buildings with a varied combination of land uses, which mainly allows housing to be near work centers and that shopping areas and leisure centers to be close to housing.

e) Facilitate spaces for pedestrians and bicycles in a green and open-space environment.

f) Favor leisure areas such as parks and gardens.

g) On the basis of the direct solutions on the diminution of resource consumption in the cities, we propose terrain surfaces destined 
to: produce energy and food, which might mean labor and employment for the inhabitants. This means a combination of urban land uses with those typically rural, agricultural and energy production. Although food and energy production at small scale and in urban zones is proposed, this does not mean that food and energy will no longer be produced in rural zones, already traditional, and at large scale. On these conditions rural-cities will be proposed to reduce and mitigate carbon emissions into the atmosphere.

\section{Results}

Not all the cities and countries produce a similar carbon footprint, because they are all different and each has its own urbanization, maintenance and operation mechanisms, and the "metabolism" varies or resource consumption changes depending on the size and characteristics of the city.

For example, the countries that produce the most $\mathrm{CO}_{2}$ e $\left(\mathrm{CO}_{2}\right.$ e understood as greenhouse effect emissions such as: methane, nitrous oxide, hydro-fluoro-carbons, etc., which equal determinate amounts of carbon dioxide emissions) are: China the country with the heaviest $\mathrm{CO}_{2} \mathrm{e}$ emissions from energy consumption, producing only in 2012, 8,106 million metric tons (Department of Energy, 2015); followed by the United States with 5,270 million metric tons; India, 1,831 million metric tons; Russia, 1,782 million metric tons; Japan, 1,259 million metric tons; Canada, 551 million metric tons; Brazil, 500 million metric tons; Mexico, 498,971 million metric tons in 2012, not counting emissions from the forest sector nor changes in land use (Department of Energy, 2015).

Indeed, most of these countries hold the largest cities in the world, namely: Shanghai (China),
New York (US), Delhi (India), Tokyo (Japan), Mexico City (Mexico) (United Nations, 2008) etc.

\section{— Which sector in Mexico impacts the most as for carbon emissions into the atmosphere?}

Human settlements in Mexico produce $\mathrm{CO}_{2}$ e a year from a number of sources, the main ones by sector, according to the Secretariat of Environment and Natural Resources (Secretaría de Medio Ambiente y Recursos Naturales, 2012), are:

, Self-consumption, 47,431 million tons.

, Electric generation, 115,537 million tons.

, Manufacture and construction industry, 56.740 million tons.

\section{- Transport, 166,412 million tons.}

, Commerce, 4,842 million tons.

, Residential, 21,460 million tons.

, Agricultural, 8,273 million tons.

, Mining and carbon handling, 6,556 million tons.

, Oil and gas industry, 76,562 million tons.

Figure 3. $\mathrm{CO}_{2}$ e emissions (million metric tons) produced in Mexico in 2012 by sector

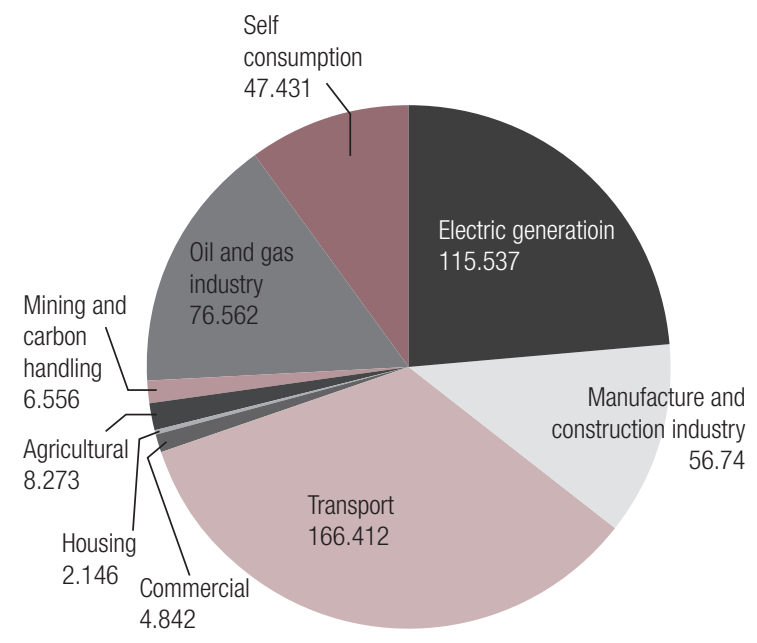

Source: Source: author's own elaboration 
In Figure 3 one observes that the transport sector is that which emits more $\mathrm{CO}_{2} \mathrm{e}$ into the atmosphere with 166,412 million tons in 2012, followed by generation and consumption of electric energy with 115,537 million $\mathrm{CO}_{2}$ e tons. In third place, one finds manufacture and construction industry with 56,74 million $\mathrm{CO}_{2}$ e tons; this way, at the time of planning close attention has to be paid to how to decrease consumption in these sectors.

Formula 1 can be used to estimate $\mathrm{CO}_{2}$ e produced in human settlements in Mexico for the next twenty years, as follows:

$$
E C O_{2}=D S L \sum_{i=F 1}^{F 9} i
$$

Data:

$$
\begin{aligned}
& D S L=20 \text { years; } \\
& \mathrm{F} 1=47,431\left(\mathrm{CO}_{2} \text { tons }\right) ; \\
& \mathrm{F} 2=115,537\left(\mathrm{CO}_{2} \text { tons }\right) ; \\
& \mathrm{F} 3=56,740\left(\mathrm{CO}_{2} \text { tons }\right) ; \\
& \mathrm{F} 4=166,412\left(\mathrm{CO}_{2} \text { tons }\right) ; \\
& \mathrm{F} 5=4,842\left(\mathrm{CO}_{2} \text { tons }\right) ; \\
& \mathrm{F} 6=21,460\left(\mathrm{CO}_{2} \text { tons }\right) ; \\
& \mathrm{F} 7=8,273\left(\mathrm{CO}_{2} \text { tons }\right) ; \\
& \mathrm{F} 8=6,556\left(\mathrm{CO}_{2} \text { tons }\right) ; \\
& \mathrm{F} 9=76,562\left(\mathrm{CO}_{2} \text { tons }\right)
\end{aligned}
$$

Substituting data:

$E C O_{2}=10,076,260$ (CO $\mathrm{CO}_{2}$ tons).

This can be helpful as an example for estimating carbon dioxide emissions of neighborhoods, urban clusters, cities, towns or regions, according to the data supplied.

— Smart planning of low-carbon cities. How can architects and urbanists reduce and mitigate the carbon footprint produced by the cities?

On the basis of impact of carbon emissions into the atmosphere, accompanied by a previous study by the author referring to the development of a model to plan low-carbon cities, which contains a series of strategies to sustainably design and plan cities (Table 1), it will be possible to determine in which points design has to be thoroughly worked in order to reduce and mitigate environmental impacts, which according to Figure 3 hit more severely in transport, generation and consumption of electricity and manufacture and construction industry or urbanization in this case.

Starting from the review of Mexican laws related to environmental protection, specific case of Ley general de equilibrio ecológico y protección al ambiente, LGEEPA (General law of ecological balance and environment protection) (Cámara de Diputados del H. Congreso de la Unión, 2012), Ley de cambio climático (Law on climate change) and the Estrategia nacional de cambio climático (Agreement on the national strategy of climate change) (Secretaría de Medio Ambiente y Recursos Naturales, 2013) and from three reference models on environmental building: Leadership in Energy and Environmental Design (LEED) (United States Green Building Council, 2014), Building Research Establishment (2013) and the Código de Edificación de Vivienda, CEV, Conavi (Code of Housing Construction) by the Comisión Nacional de Vivienda (2015) (National Housing Commission of the Mexican Government), a general proposal was generated to reduce the carbon footprint in 
cities from the urban-architectural standpoint and that is summarized in Table 1 by entry, and by each entry, strategies of sustainable design in construction and urbanization.

Table 1. Sustainable design strategies in construction and urbanization by environmental aspect (model proposed to reduce carbon footprint in the cities)

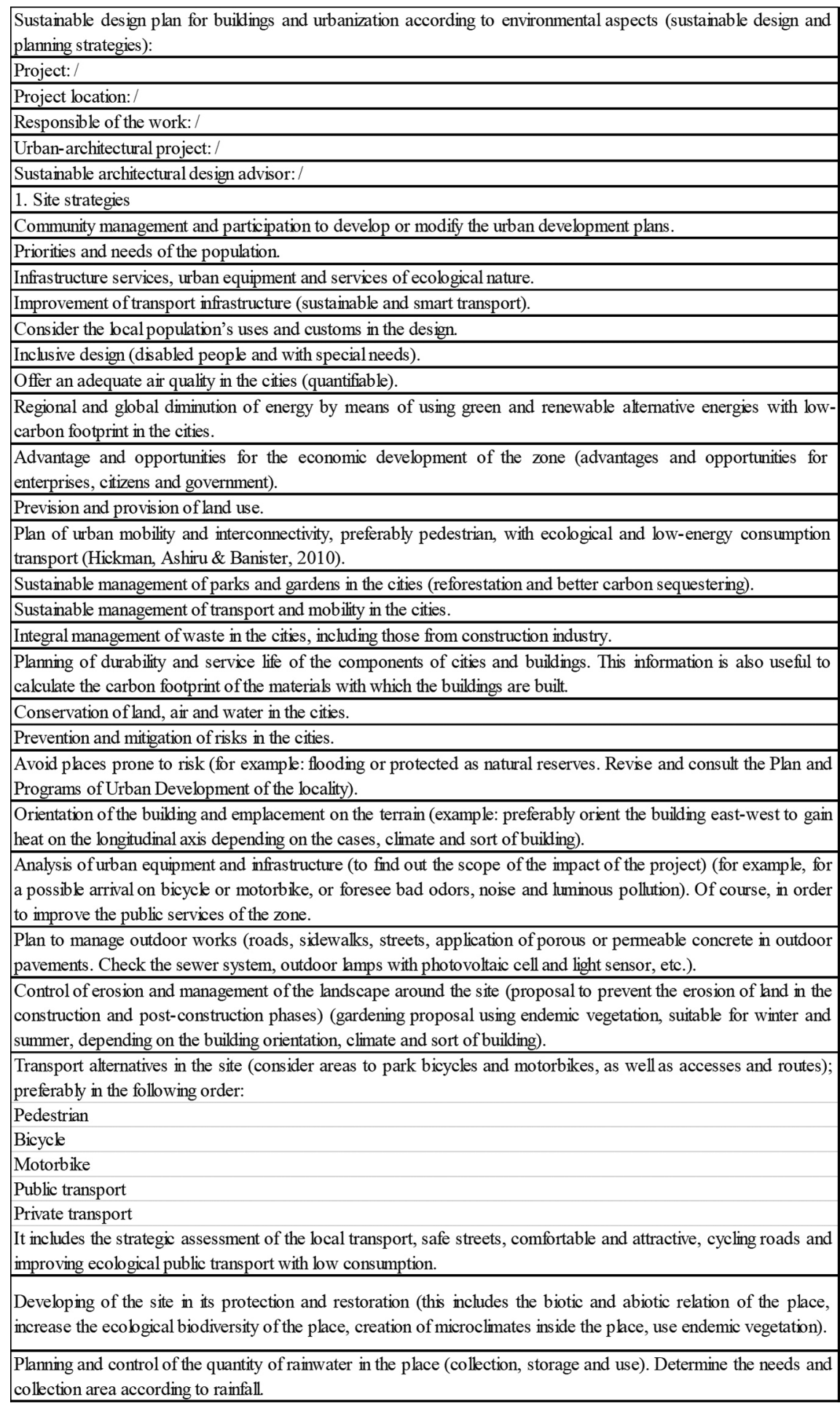


Reduction of heat islands (for example: green roofs on the south side, gardens and trees in exteriors and solar protectors in the south façade) (installation of a velarium in the roof that partially covers it) (implementation of permeable pavements made of porous concrete and tiled-grass).

Reduction of luminous, acoustic and odor polhution (by means of natural barriers).

Improvement of the ecological value of the place (for instance, by means of green areas, use of eco-techniques and conservation of the biodiversity of the place).

2. Water strategies

Minimal piping and installations and efficiency in their connections (check piping installation).

Secure and measure of the amount of water (in the entire building or its parts or as a whole).

Additional installations both in piping and connections in order to reduce water consumption between 10 and $40 \%$. Use of water-saving sinks, urinals and toilets; for instance, for example gel urinals and other saving devices, use of time sensors in sinks, urinals, etc.).

Reduction of water consumption in the network with rainwater (20\% approx.) (calculated collection surface).

Use of water in cooling towers in warm climates.

Use of systems to use greywaters for non-potable applications (it inchudes biological and chemical treatment) (using greywaters and store and take them using gravity to urinals and toilets or take them to a cistern to later by means of pumping take them to a water tank in the roof).

Blackwater treatment (revise the regulation on potable water or corresponding technical norm).

3. Energy strategies

Passive control for energy performance in buildings:

Orientation of the building to advantageously use the gain or loss of heat (example: reduce heat gain in April and May, mainly in south façade).

Optimize the building envelop to improve thermal performance (examples: thermal insulation in the north, sealing of windows and constructive junctures, possible double-paned windows in the north façade).

Offer natural light (skylights, domes, blinds and sunshades) (check the staircase, possibly light with change in tiles or natural light with optical fiber in case of basements)

Offer natural ventilation (direct and crossed ventilation, windward and leeward, windows, vents, passive fans). NB check lattice works and provide more air holes to produce crossed ventilation, check in the lattice drawings) (check dominant winds in the hottest months).

Offer eco-technologies for an adequate heat gain or loss (mainly to ventilate and cool) (thermally insulate façades).

Control humidity inside the building (by means of adequate natural ventilation)

Active control for energy performance in buildings:

Artificial light (reduce energy using saving lamps, sensors and intelligent actuators).

Artificial ventilation (air-conditioning and heating systems only if necessary; use of electric fans combined with intelligent or automated sensors and actuators) (could we totally or partially do away with air conditioning by means of passive acclimatization systems? Yes, by means of a cooling tower and crossed illumination) (and, could we avoid artificial heating? Yes, by means of passive heating systems).

Gain or bss of artificial heat (air-conditioning and heating systems combined with intelligent or automated systems).

Artificial and intelligent humidification and de-humidification (implement humidity sensors) (use of humidifiers and dehumidifiers in heavy humidity zones).

Efficient design of electromechanical systems:

Offer adequate installation of artificial light (lamps, phases, loads, wires).

Maximize the performance of electromechanical systems (possible use of electro capacitors)

Efficient use of equipment and apparatuses (that meet the corresponding environmental technical energy-saving norm).

Installation of electric devices that reduce the consumption of electric energy (capacitors).

Use of low environmental impact energy:

Use of renewable energies or other alternative sources (photovoltaic and passive water heating) (propose the machine room for the PV system on the rooftop) (make a PV calculation to cover $10-15 \%$ of the total installed load capacity).

At local level consider wind turbines, mini-hydro, geothermal and other hydrogen-based alternative energies

Simulate the total amount of energy to be used:

Integrate the systems and reduce the total energy use to $30 \%$ (estimate $20 \%$ for this case in relation to conventional buildings).

Measure carbon emissions from the effect of transport energy.

Use of imnovative technology for the energy systems.

4. Comfort strategies inside and outside the buildings

Air quality

Control humidity and prevent infectious agents (integrate humidity sensors in the air-conditioning). 
Offer good ventilation for better thermal and pathogenic control (natural and artificial ventilation).

Tobacco control (using signals).

Control of air quality inside the building (plan and monitoring using $\mathrm{CO}_{2}$ sensors).

Human factors:

Offer good thermal conditions (passive and active design) (offer a comfort zone around $22^{\circ} \mathrm{C}$ ).

Offer good illumination (passive and active design) (offer the necessary huminance both naturally and artificially).

Offer good ventilation (passive and active design) (offer air interchange per second in 1/s; approx. $81 \mathrm{~s}$ per user).

Offer good acoustic conditions (passive and active design) (for instance 35-48 dB for an office environment).

Offer good vibration conditions (passive and active design) (check loads in the structure, glass panes and windows sealing and general adjustment of accessories and equipment).

Offer adequate visual relief on the outside (passive design). Check conditions.

Control external bad odors (passive and active design).

Control of the comfort of occupation and ergonomics (passive and active design) (check furniture according to architectonic spaces and activities to be performed).

Control of humidity conditions (passive and active design), check natural ventilation to reach an ideal humidity percentage between 30 and $50 \%$.

Other factors:

Cleaning and maintenance of the building (foresee and produce a cleaning manual).

Products and equipment used in cleaning and maintenance (biodegradable).

Internal control of chemical and physical pollutants (cleaning and maintenance manual)

5. Strategies for construction materials

Assessment of material properties and diminution of volumes at the construction site (check utilized materials).

Life cycle analysis to reduce their carbon footprint both in their production and disposal.

Raw material extraction:

Use low environmental impact materials over their life cycle with low-carbon footprint (perform studies and select low environmental impact materials and low carbon content and dangerous toxic materials).

Production:

Use of recovered and remanufactured materials (reusable materials in good conditions).

Use of materials and products with recycled contents (check availability in the region).

Use of renewable materials (woods, natural fibers, adobes).

Distribution:

Use of locally produced materials (produce a list of the materials of the region).

Installation and construction:

Use of materials with low emission of volatile substances. Avoid materials such as sealants and paints with a high index of volatile organic compounds.

Use of durable materials. Check service life stated by the producer, or estimate or calculate it.

Reuse and recycling:

Use of reusable, recyclable and biodegradable materials (produce a list of ecological materials, mainly according to Mexican technical norms).

6. Strategies for construction waste

Reduce waste and scrap over the entire life cycle. Control waste over the entire life of the building (programming).

Appropriate management of hazardous waste. Control waste over the entire life of the building under Mexican norms.

Produce a maintenance manual to reduced waste over the entire life cycle of the building (produce a maintenance manual for the building) (solid waste management over its entire service life).

Resource conservation:

Reuse of existing buildings (reuse of existing buildings or parts of buildings in the set).

Design to utilize a lower amount of materials. Reduce architectonic spaces and construction volumes.

Design of multi-functional or adaptable buildings (flexible architectonic design).

Design buildings to be dismantled, not demolished (use of prefabs and prefabrication systems).

Waste management:

Save and recycle waste from demolition (including construction waste).

Reduce, reuse and recycle waste from construction (incorporate waste into construction components).

Reduce and recycle the packing materials (separate and recycle bags).

Reduce and recycle waste from the building users (separate trash during service life).

Reduce and correctly dispose of hazardous waste (consult specialists in the case of using dangerous materials during and after construction). 
- Designing a low-carbon urban cluster. How can we reduce the consumption of resources in the cities in order to improve their metabolism without decreasing their inhabitants' quality of life?

As commented in the introductory part of the present work, the hypothesis which this paper is based upon lies in the fact that smart urban planning shall be focused on the design of low-carbon urban clusters (Figure 2), composed of neighborhoods with several land uses (at an urban-architectural or meso-scale) arranged in such manner that they can reduce environmental impacts in the cities. For such ends, the aim of this document is to define and detail the main characteristics of a low-carbon urban cluster that works as a pattern and that allows the configuration of low-carbon and/or low environmental impact cities.

According to the proposed methodology, Figure 4 presents a low-carbon urban cluster designed as an architectural-urban response to reduce and mitigate carbon footprint in current cities.

Figure 4 shows a low-carbon urban cluster which is based, firstly, on the sustainable design strategies presented in the Table 1 of the present document, and also on the strategies listed above in methodology section (strategies and design key points), which refer to the design of low-carbon urban clusters.

The cluster is a set of buildings and urban components that enable a number of urban land uses; these compose the cities and can be used as design patterns to plan low-carbon cities, mainly because it helps incorporate land uses traditional to rural zones (agriculture and energy production) into urban areas. It is very important to underscore that the smart design of this sort of urban configuration is accompanied with the use and application of environmental design strategies, as it is the case of the contents of table 1 and other models such as the technical manual of

Figure 4. Low-carbon urban cluster

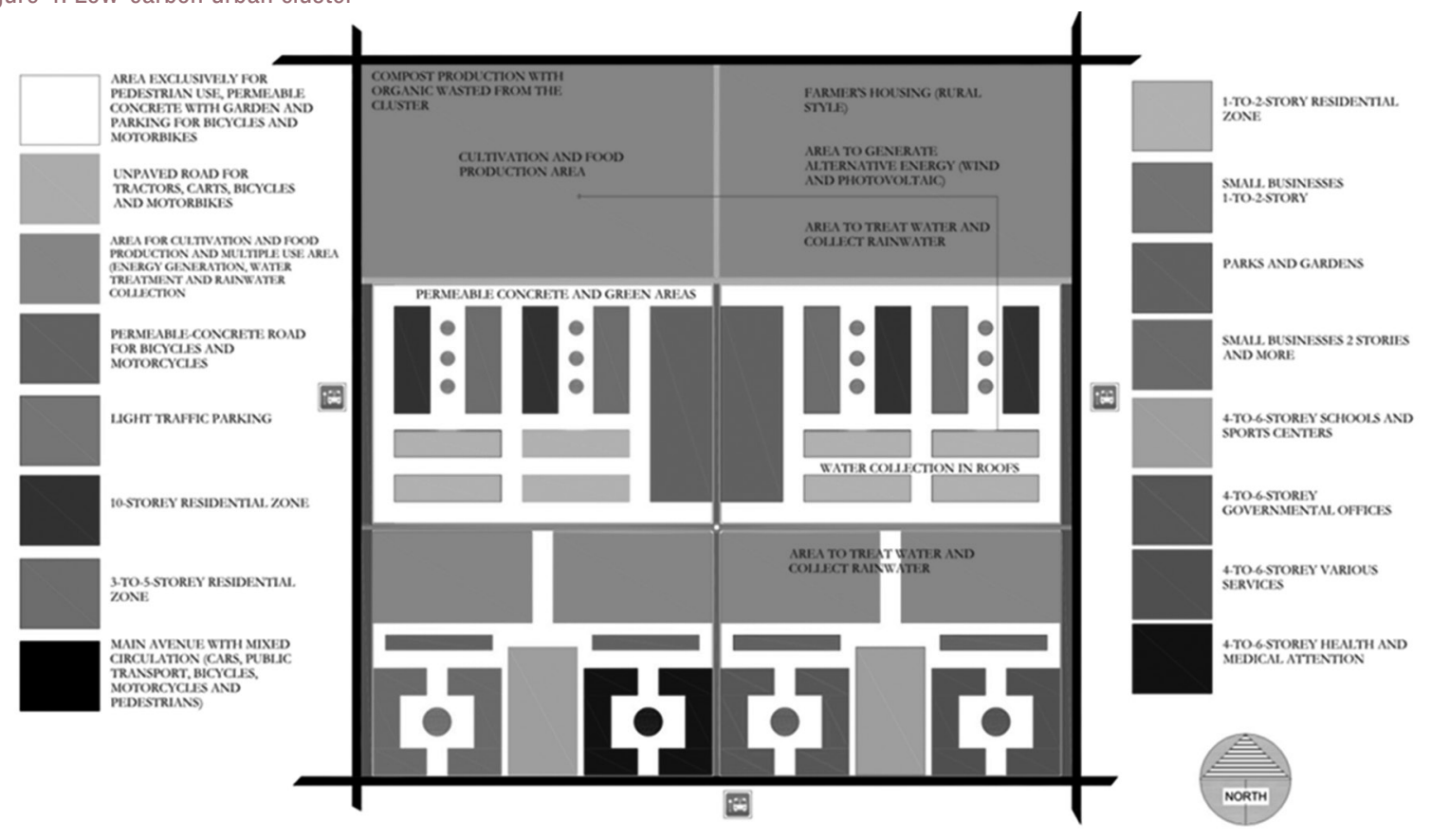

Source: authors' own elaboration based on the methodology proposed in this document 
communities of European model Breeam (Building Research Establishment, 2013).

The example of urban cluster in Figure 4 is a proposal of the authors, in the first place to present a solution to the design and planning of low-carbon cities and other environmental impacts that affect the development of Mexican cities. For example, we propose areas to produce food with irrigated plots inside the cluster itself, where water mainly comes from rainwater collection and the biological treatment of greywaters from the very buildings in the cluster.

This paper also proposes high or middle urban density planning, because this allows an important population concentration, thus holding most of the important activities of a city, except for industrial activity, which is proposed to be in an area far from the main clusters. Additionally, it also suggests that inside the cluster only pedestrian or cycling mobility is allowed, this will noticeably decrease the use of particular vehicles. Parking space is suggested, as shown in Figure 4 , in the periphery of the cluster, right next to the main avenues; this will make that inside the cluster there is only pedestrians, bicycles and sporadically motorbikes and tractors.

It also advises that these green cultivation areas are also utilized to produce alternative energy, at small scale, by means of various technological resources such as wind turbines, photovoltaic panels or other green and carbon-emission free sources that secure the use of energy in the cities without resorting $100 \%$ to high environmental impact energies.

As for water infiltration into groundwater, the entire cluster surface is proposed to be permeable; gardens and cultivation zones, obviously $100 \%$; all the circulation areas, for pedestrians, bicycles and tractors with materials that allow $70-80 \%$ of permeability.

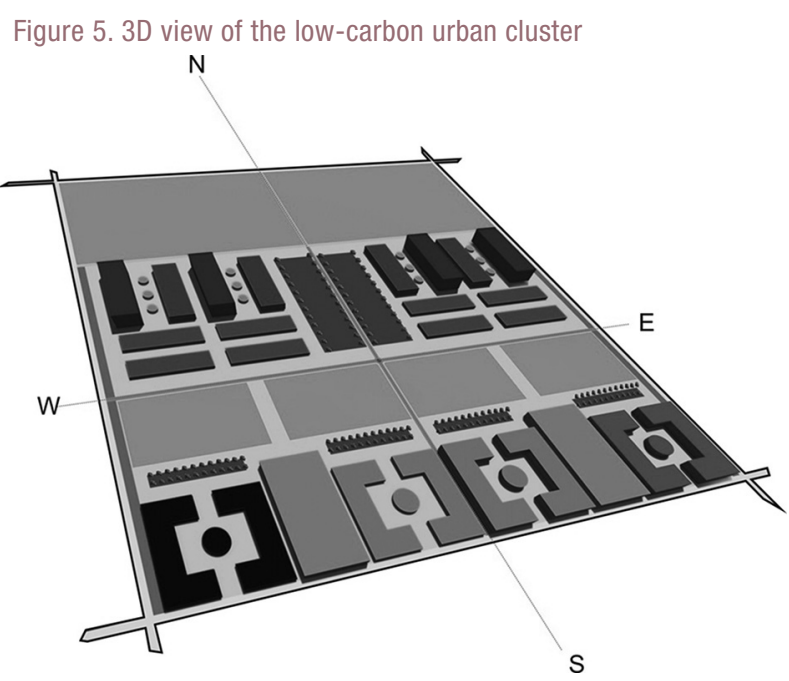

Source: drawing by Silverio Hernández-Moreno and Sebastián Alejandro Carrión-Sánchez

On the other side, the array of blocks of buildings (Figure 5) allows a better distribution of sunlight, orienting most of the façades along the east-west and also giving a relevant place to the south side for the case of cities in the northern hemisphere, which besides allows better heat gain, better illumination and ventilation (Figure 5).

\section{Discussion and conclusions}

Given that traditional models used for planning and design cities cannot deliver low carbon cities then we must now focus to transform our economies based on fossil fuels to low-carbon economies, which also should be included environmental services in the cities and towns that focus on local food production and alternative energy generation through proper planning of land uses.

On the other hand, trying incentives from governments at all levels to design and plan green infrastructure in cities. This will not only support sustainability in cities but it is a smart way 
to mitigate environmental impacts in rural areas too, improving the quality of life of the people on both sides.

As partial solution urban planning should be supported on the design of low-carbon urban clusters composed of neighborhoods with various land uses (at an urban-architectural or meso-scale) arranged in such manner that they reduce the environmental impacts in the cities, therefore each urban and architectural configuration has a determinate level or degree or carbon footprint.

Neighborhoods and blocks edified from urban clusters incorporate in their urban land uses, those typical of the rural sphere such as agriculture and small and mid-scale energy production, in views of offering solutions to the largest problems of urban and rural zones.

The design of urban clusters of low carbon could give partial solutions to gradual change from high carbon cities to low carbon cities, especially in economies that base their development on fossil fuels such as Mexico and many countries in the world.

These are derived general conclusions:

, Cities are complex systems that evolve over time and it becomes difficult to separate their life cycle phases and predict their durability and service life accurately.

, Neither every city nor every country produce similar carbon footprints, as they are different and have their own urbanization mechanisms.

, Fast and uncontrolled urbanization is partially a product of the inoperative design of neighborhoods, linked to bad planning of urban land uses.

, Most of the cities in the world are based on an economy of fossil-energy consumption with heavy carbon emissions into the atmosphere, which produces the already known global warming and climate change.

> The consumption of fossil energy for the construction and operation of all the cities in the world is responsible for about $50 \%$ of the total damage from global warming.

, Human development plans must contemplate suitable and productive land uses, both in the rural and urban spheres.

, Smart urban planning should be based on the design of low-carbon clusters, composed of neighborhoods with various land uses (at an urban-architectonic or meso-scale) arranged in such manner that they can reduce environmental impacts in the cities and towns.

- Land uses also heavily influence the urban dynamics of the cities as they can increase or decrease to a large extent the environmental, economic, and "urban metabolism" effects proper to the city.

> The cluster of the present proposal can be useful as a design pattern to plan rural-cities, propitiating solutions to generate employment, produce food and energy at small- and midscale in the cities, thus helping regional sustainable development and improving the quality of life of many urban inhabitants nowadays and in a near future.

\section{Acknowledgments}

Scientific research paper, product of work done in the Autonomous University of the State of Mexico about the line of research on the environment in architecture and urban planning, where external co-authors participate, specializing in 
sustainable regional development and carbon capture.

\section{Bibliography}

Bin Marsono, A. K., \& Balasbaneh, A. T. (2015). Combinations of Building Construction Material for Residential Building for the Global Warming Mitigation for Malaysia. Construction and Building Materials, 85, 100-108. https://doi. org/10.1016/j.conbuildmat.2015.03.083

Building Research Establishment. (2013). Breeam Communities Technical Manual. Retrieved from https://tools.breeam.com/bre_ PrintOutput/BREEAM_Communities_0_1.pdf

Cámara de Diputados del H. Congreso de la Unión. (2012, April 6). Ley general del equilibrio ecológico y la protección al ambiente. Mexico City: Diario Oficial de la Federación.

Carmin, J. (2009). Preparing Cities for Climate Change: An International Comparative Assessment of Urban Adaptation Planning. MIT-ICLEI Climate Adaptation Survey Instrument. Cambridge: MIT Department of Urban Studies and Planning.

Centro Mario Molina. (2014). Programa de acción climática de la Ciudad de México. Mexico City: Author.

Chase, T. N., \& Lawrence, P. J. (2010). Investigating the Climate Impacts of Global Land Cover Change in the Community Climate System Model. International Journal of Climatology, 30(13), 2066-2087.

Cheung, M., \& Fan, J. (2013). Carbon Reduction in a High-Density City: A Case Study of
Langham Place Hotel Mongkok Hong Kong. Renewable Energy, 50, 433-440.

City of Copenhagen, Technical and Environmental Administration. (2012). CPH 2025 Climate Plan: A Green, Smart, and Carbon Neutral City. Copenhagen: Authors.

Comisión Nacional de Vivienda. (2015). Código de edificación de vivienda CEV. Mexico City: Author.

Department of Energy. (2015). Total Carbon Dioxide Emissions from the Consumption of Energy 2012. Washington: Author.

Drake, J. B. (2014). Climate Modeling for Scientists and Engineers. Philadelphia: Society for Industrial and Applied Mathematics.

Fernandez, J. E. (2014, June 2). Scales of Urban Metabolism. Conference presented at 2014 International Sustainable Campus Network. Boston: Urban Metabolism Group MIT.

Fouquet, M., Levasseur, A., Margni, M., Lebert, A., Lasvaux, S., Souyri, B., ... Woloszyn, M. (2015). Methodological Challenges and Developments in LCA of Low Energy Buildings: Application to Biogenic Carbon and Global Warming Assessment. Building and Environment, 90, 51-59. https://doi.org/10.1016/j. buildenv.2015.03.022

Hickman, R., Ashiru, O., \& Banister, D. (2010). Transport and Climate Change: Simulating the Options for Carbon Reduction in London. Transport Policy, 17(2), 110-125. https://doi. org/10.1016/j.tranpol.2009.12.002

La Roche, P. (2012). Carbon-Neutral; Architectural Design. Washington: CRC Press.

McKinsey \& Company. (2009). China's Green Revolution: Prioritizing Technologies to Achieve Energy 
and Environmental Sustainability. Retrieved from https://www.mckinsey.com/business-functions/sustainability-and-resource-productivity/ our-insights/chinas-green-revolution-prioritizing-technologies-to-achieve-energy-and-environmental-sustainability

McPhearson, T., Haase, D., Kabisch, N., \& Gren, A. (2016, in press). Advancing Understanding of the Complex Nature of Urban Systems. Ecological indicators. https://doi.org/10.1016/j. ecolind.2016.03.054

Molina, M. (2014). Expansión urbana y cambio climático. Ciencia, 65(4), 10-13.

Secretaría de Medio Ambiente y Recursos Naturales. (2012). Quinta comunicación nacional ante la Convención marco de las Naciones Unidas sobre el cambio climático. Mexico City: Author.
Secretaría de Medio Ambiente y Recursos Naturales. (2013, June 3). Acuerdo por el que se expide la Estrategia nacional de cambio climático. Diario Oficial de la Federación.

United Nations [UN]. (2008). World Urbanization Prospects: The 2007 Revision. Washington: Author.

United States Green Building Council. (2014). LEED USA ${ }^{\mathrm{TM}}$, Version 4.0. Washington: Author.

Van der Werf, G. R., Morton, D. C., De Fries, R. S., Olivier, J. G. J., Kasibhatla, P. S., Jackson, R. B., ... Randerson, J. T. (2009). CO 2 Emissions from Forest Loss, Nature Geo Sci, 2(11), 737-738.

Wang, F., \& Prominski, M. (Eds.). (2016). Urbanization and Locality. New York: Springer. 